\title{
Influence of High and Low Levels of Plant-Beneficial Heavy Metal lons on Plant Growth and Development
}

\author{
Namira Arif ${ }^{1}$, Vaishali Yadav ${ }^{1}$, Shweta Singh ${ }^{1}$, Swati Singh ${ }^{1}$, Parvaiz Ahmad ${ }^{2,3}$, \\ Rohit K. Mishra ${ }^{4}$, Shivesh Sharma ${ }^{4,5}$, Durgesh Kumar Tripathi ${ }^{4,6 *}$, N. K. Dubey ${ }^{6}$ and \\ Devendra K. Chauhan ${ }^{1 *}$ \\ ${ }^{1}$ D D Pant Interdisciplinary Research Laboratory, Department of Botany, University of Allahabad, Allahabad, India, \\ ${ }^{2}$ Departments of Botany, Sri Pratap College, Srinagar, India, ${ }^{3}$ Botany and Microbiology Department, College of Science, King \\ Saud University, Riyadh, Saudi Arabia, ${ }^{4}$ Centre for Medical Diagnostic and Research, Motilal Nehru National Institute of \\ Technology, Allahabad, India, ${ }^{5}$ Department of Biotechnology, Motilal Nehru National Institute of Technology Allahabad, \\ Allahabad, India, ${ }^{6}$ Centre of Advanced Study in Botany, Banaras Hindu University, Varanasi, India
}

\section{OPEN ACCESS}

Edited by:

Sarvajeet Singh Gill, Maharshi Dayanand University, India

Reviewed by:

Namik Mammad Oglu Rashydov, The National Academy of Sciences of Ukraine, Ukraine

Francesco Di Natale, University of Naples Federico II, Italy

*Correspondence: Durgesh Kumar Tripathi dktripathiau@gmail.com

Devendra K. Chauhan dkchauhanau@yahoo.com

Specialty section:

This article was submitted to

Environmental Toxicology,

a section of the journal

Frontiers in Environmental Science

Received: 30 June 2016 Accepted: 12 October 2016 Published: 21 November 2016

Citation: Arif N, Yadav V, Singh S, Singh S, Ahmad P, Mishra RK, Sharma S, Tripathi DK, Dubey NK and Chauhan DK (2016) Influence of High and Low Levels of Plant-Beneficial Heavy Metal Ions on Plant Growth and Development

Front. Environ. Sci. 4:69. doi: 10.3389/fenvs.2016.00069
Heavy metals (HMs) exists in the environment in both forms as essential and non-essential. These HM ions enter in soil biota from various sources like natural and anthropogenic. Essential HMs such as cobalt (Co), copper (Cu), iron (Fe), manganese $(\mathrm{Mn})$, molybdenum (Mo), nickel (Ni), and zinc (Zn) plays a beneficial role in plant growth and development. At optimum level these beneficial elements improves the plant's nutritional level and also several mechanisms essential for the normal growth and better yield of plants. The range of their optimality for land plants is varied. Plant uptake heavy metals as a soluble component or solubilized them by root exudates. While their presence in excess become toxic for plants that switches the plant's ability to uptake and accumulate other non-essential elements. The increased amount of HMs within the plant tissue displays direct and indirect toxic impacts. Such direct effects are the generation of oxidative stress which further aggravates inhibition of cytoplasmic enzymes and damage to cell structures. Although, indirect possession is the substitution of essential nutrients at plant's cation exchange sites. These ions readily influence role of various enzymes and proteins, arrest metabolism, and reveal phytotoxicity. On account of recent advancements on beneficial $\mathrm{HMs}$ ions $\mathrm{Co}, \mathrm{Cu}, \mathrm{Fe}, \mathrm{Mn}, \mathrm{Mo}, \mathrm{Ni}$, and $\mathrm{Zn}$ in soil-plant system, the present paper: overview the sources of HMs in soils and their uptake and transportation mechanism, here we have discussed the role of metal transporters in transporting the essential metal ions from soil to plants. The role played by $\mathrm{Co}, \mathrm{Cu}, \mathrm{Fe}$, $\mathrm{Mn}, \mathrm{Mo}, \mathrm{Ni}$, and $\mathrm{Zn}$ at both low and high level on the plant growth and development and the mechanism to alleviate metal toxicity at high level have been also discussed. At the end, on concluding the article we have also discussed the future perspective in respect to beneficial HM ions interaction with plant at both levels.

Keywords: essential heavy metals, environment, tronsporters, uptake, plant, growth

\section{INTRODUCTION}

Heavy metal like cobalt $(\mathrm{Co})$, copper $(\mathrm{Cu})$, iron $(\mathrm{Fe})$, manganese $(\mathrm{Mn})$, molybdenum $(\mathrm{Mo})$, nickel $(\mathrm{Ni})$, and zinc $(\mathrm{Zn})$ enters in soil from various sources such as mining, foundries, smelters, combustion, and agriculture (Nagajyoti et al., 2010). Plant genomes encode a number of transporters that are specific in their substrate specificities, expression, and in cellular localization 
to manage the translocation of these metals into the whole plant (Colangelo and Guerinot, 2006; Hwang et al., 2016). These metals are acting a beneficial role for plant growth, development, and productivity at an optimum concentration in the form of the essential micronutrient (Singh et al., 2016). To grow and complete the life cycle plants use these essential micronutrients (Wuana and Okieimen, 2011). The plant takes these essential heavy metals like iron, zinc, copper, and manganese from the soil due to concentration gradients and selective uptake of these metals (Peralta-Videa et al., 2009). These ions enthusiastically affected the function of many enzymes and cellular metabolism. These metals also play a prominent role in the synthesis of protein, nucleic acids, photosynthetic pigment, and it also take part in the structural and functional integrity of cell membranes (Oves et al., 2016). For instance Copper is an essential heavy metal which actively takes part in the photosynthesis (Gad, 2012). Manganese is an important constituent of various metabolic enzyme like mallic dehydrogenase and oxalosuccinic decarboxylase (Millaleo et al., 2010), Cobalt found in the form of Vitmain B12 (Barker and Pilbeam, 2015), while $\mathrm{Fe}$ act as a cofactor in cytochrome (Thomine and Lanquar, 2011). Although the concentration of these heavy metal ions in soils is severely altered by the arbitrary human activities and through the various natural process (Singh et al., 2011). The enhanced concentration of these beneficial ions poses a toxic effect into the plant cells. These effects may be substituted of essential functional groups, cellular damage, generation of reactive oxygen species (ROS), disturbance in the various metabolic reaction by altering the enzymatic activity (Anjum et al., 2015). Regarding the above facts, it is noticeable that only a limited amount of these beneficial heavy metals is essential for the plant growth and metabolic function. Therefore, in the current article we elaborately reviewed various studies regarding heavy metals sources, their uptake mechanism, essential transporters and also discuss about the constructive, and destructive properties of heavy metals in response to their concentration.

\section{SOURCE OF VARIOUS BENEFICIAL HEAVY METAL IONS}

There are numerous source of HMs contamination in the surroundings like natural, and anthropogenic including agricultural, industrial, domestic, and atmospheric (Bing et al., 2011). The most imperative natural source of HMs contamination is geological bedrock and rock substratum (Tchounwou et al., 2012). The composition and amount of heavy metal specifically relies on the type and concentration of rocks and as well as on the weathering process (Wuana and Okieimen, 2011). The inorganic and organic fertilizers are the agricultural sources of heavy metal contagion, liming, sewage disposal, irrigation water, and pesticides are the main cause of heavy metal discharge in the soil (Chopra et al., 2009). A case study around peri-urban and urban-industrial clusters in Ghaziabad, India, reveals that waste water irrigation is responsible for the heavy load of heavy metal in agricultural soils, crops, and vegetables (Chabukdhara et al., 2016). Mining refinement such as spoil heaps, tailings, transportation of ores, smelting metal finishing, and recycling of metals are the industrial process that liberates the HMs in the environment (Tchounwou et al., 2012), For instance, Deng et al. (2016) through their study suggested that the atmospheric deposition is the major cause of $\mathrm{Pb}, \mathrm{Cd}, \mathrm{Cu}, \mathrm{Cr}$, and $\mathrm{Zn}$ accumulation in plants of peri-urban and smelting contaminated sites in Baoji, China. While the explosion, landfills, and transportation like automobiles, diesel powered vehicles, and aircraft are also the source of heavy metal pollution (Wuana and Okieimen, 2011). Anthropogenic activities like coal mining, waste combustion, and steel processing are the major cause of rising level of zinc (Lottermoser, 2010). The excessive injudicious and unregulated use of $\mathrm{Cu}$ fungicides, bactericides and Chromium $(\mathrm{Cr})$ contaminates the environment through the electroplating processes and waste material pesticides to control plant diseases and pest that has resulted in $\mathrm{Cu}$ accumulation in surface layer of agricultural soil (Mackie et al., 2012).

\section{UPTAKE AND TRANSLOCATION OF BENEFICIAL HEAVY METAL IONS}

Soil is the reservoir of various HMs contaminations and has strong property of cation exchange capacity. Among these HMs some of the metals such as $\mathrm{Co}, \mathrm{Cu}, \mathrm{Cr}, \mathrm{Fe}, \mathrm{Mg}, \mathrm{Mn}, \mathrm{Mo}$, $\mathrm{Ni}, \mathrm{Se}$, and $\mathrm{Zn}$ are essential element, that are required in very small amounts for optimum plant growth and development (Alloway, 2013). These beneficial HMs plays several biochemical and physiological task in plants and also regarded as significant constituents of various cellular enzymes moreover actively take part in several oxidation-reduction reactions (Emamverdian et al., 2015). For instance, Fe easily reduced and oxidized in various biochemical processes and also an important cofactor of many enzymes which involves in the respiration, photosynthesis, and nitrogen assimilation (Hell and Stephan, 2003). $\mathrm{Zn}$ is a vital structural constituent of protein and also acts as a cofactor of several enzymes (McCall et al., 2000). Zn absorption, uptake, and accumulation in plants occurs throught the involvement of Zinc transporters and metal chelatiors into the plant (Gupta et al., 2016). Cu also acts as an essential element for plant growth by participating in many redox-active reactions. Mn plays an important role in detoxification of ROS (Ducic and Polle, 2005). Plant absorb essential and non-essential element from the soil in response to concentration gradient and selective uptake of ions or by diffusion (Peralta-Videa et al., 2009). The absorption level of different element relies upon the different plant species. Root plays a significant role in the active uptake of metal ions. The mechanism is mainly started by the absorption of metal ions in the root tissue, the ions of $\mathrm{Co}, \mathrm{Cu}, \mathrm{Fe}, \mathrm{Mn}, \mathrm{Mo}, \mathrm{Ni}$, and $\mathrm{Zn}$ dissociates from its complex forms at the root surface. The metals are heavily accumulated into the root apoplast (Krzesłowska, 2011). The adsorption of heavy metals on the root surface takes place in cationic form with negative cell wall due to the presence of cellulose, pectins, and glycoproteins that work as specific ion exchangers. The adsorption and translocation of metal ions occurs in xylem and phloem tissue through the root by two ways 
known as apo-plastic and symplastic (Hossain et al., 2012). The apoplastic transportation occur through the intercellular spaces by the diffusion of metal ions in the root cell through the soil solution, while the symplastic transportation of metal ions takes place through the plasma membrane by the different carrier or transporters (Barberon and Geldner, 2014).

\section{METAL TRANSPORTERS}

Beneficial metal nutrient elements like $\mathrm{Co}, \mathrm{Fe}, \mathrm{Mn}, \mathrm{Cu}, \mathrm{Mo}, \mathrm{Ni}$, and $\mathrm{Zn}$ are essential for normal plant growth and development (Loftleidir, 2005). These metal nutrients occur in the soil in limited amount and transported to the plant in a homeostatic way by the metal transporters (Krämer et al., 2007). Several workers disclose the role of transporters in beneficial metal adsorption and translocation in plants (Krämer et al., 2007; Puig et al., 2007). Grotz and Guerinot (2006) reported the uptake of $\mathrm{Fe}$ and $\mathrm{Zn}$ ion which is mediated by a group of transporters belonging to the ZIP family like ZRT (Zinc regulated transporters) and IRT (Iron regulated transporters) proteins in higher plant. Kim and Guerinot (2007) stated in his article that IRT1 is able to mediate the transfer of multiple metals including Fe, Mn, Zn, and Cd. Hussain et al. (2004) in their article "P-Type ATPase heavy metal transporters with roles in essential zinc homeostasis in Arabidopsis" reported the role of HMA2 (Heavy metal ATPase) and HMA4 in essential Zn homeostasis (Table S1). The absorption and translocation of copper occurs in plants by the CTR (Copper transporter) and COPT1 (Copper transport protein; Sancenón et al., 2003). Cu transported in plants by the two types of transporters first one is P-type ATPases belonging to the HMA family and second one is RAN1 (Responsive-to-Antagonist) also known as HMA7 (Sancenón et al., 2003; Table S1). Colangelo and Guerinot (2006) stated in their article that YSL (Yellow strip-like) members have been involved in the transportion of metals such as Fe and Mn ions in rice plants (Table S1). Mizuno et al. (2005) reported the three ZIP/NRAMP (natural resistance-associated macrophage protein) transporter genes from a Ni hyperaccummulator plant Thalpsi japonicum and their Ni-transport abilities (Table S1). The obtained result suggested that ZIP/NRAMP transporter contributes in Ni homeostasis in plants (Table S1). TjZNT1 has $\mathrm{Zn}, \mathrm{Cd}$ and $\mathrm{Mn}$ ion transportation ability and TjZNT2 also has $\mathrm{Zn}$ and Mn transporting capacity, while TjNRAMP4 could only transport Ni (Table S1).

\section{IMPACT OF BENIFICIAL HEAVY METALS ON PLANTS AT LOW LEVEL}

Beneficial HMs like Co, Cu, Fe, Mn, Mo, Ni, and Zn (Blaylock and Huang, 2000) at low level or under an optimum range induces essential biochemical and physiological reactions in plants (Nagajyoti et al., 2010). Cobalt plays an essential role in plant growth development by regulating plant water utilization and reducing transpiration rate (DalCorso et al., 2014). Gad and Hassan (2013) carried out an experiment on tomato plant with Co application at $7.5 \mathrm{ppm}$, which enhanced the growth, yield, nutrient levels, and chemical constituents of tomato plant with better quality of fruits (Table 1; Figure 1). Copper being an essential HM, at low amount helps in enhancing the plant photosynthesis (Mahmood and Islam, 2006). It involves in physiological functions and is a crucial cofactor for many metaloprotiens (Yruela, 2005). Copper is a vital element for plant growth and development (Table 1; Figure 1), also proved as a micronutrient for plants (Kabir et al., 2009) and it plays an imperative function in $\mathrm{CO}_{2}$ assimilation and ATP synthesis (Pichhode and Nikhil, 2015). Cu at optimum level is valuable element of various proteins such as plastocyanin of photosynthetic system and cytochrome oxidase of respiratory electron transport chain in plants (DemirevskaKepova et al., 2004). Considering Fe as beneficial HM for plants, it is essential for respiration, photosynthesis, nitrogen fixation (Table 1; Figure 1), various cellular processes like DNA synthesis and hormone production (Becana et al., 1998; Møller et al., 2007), chloroplast development and chlorophyll biosynthesis (Møller et al., 2007). It is a constituent of heme protein (cytochromes, catalase, peroxidase, and leghemoglobin) and iron sulfur protein (ferredoxin, acontiase, and SOD; Gill, 2014). Low pH level of soil makes the $\mathrm{Fe}$ more readily available for the plant root $\mathrm{Fe}$ uptake (Marschner, 1995; Asati et al., 2016). Manganese is a vital plant nutrient element; predominantly it plays an imperative role in structuring photosynthetic proteins and enzymes and positively affects the biosynthesis of growth substances (Table 1; Figure 1) and the gene expression (Frassinetti et al., 2006). It also regulates the metabolism of carbohydrates and lipids, relocation of trace ions, and other HMs in soils (Marschner and Rengel, 2007). Shenker et al. (2004) propounded about the Mn nutritious possessions on tomato (Lycopersicon esculentum) and role of $\mathrm{Mn}$ on enhancing growth, chlorophyll content and SOD (superoxide dismutase) activity of tomato plant at 7.6 and $8.6 \mathrm{mg} \mathrm{kg}^{-1} \mathrm{Mn}$ concentration (Table 1; Figure 1). In significant perspective of Mo, it is a constituent of more than 60 metalloenzymes and proteins (Kaiser et al., 2005; Mendel and Schwarz, 2011). Plant requires Mo in the range of 0.1-1.0 ppm (McGrath et al., 2010), enhances the total chlorophyll concentration in plants (Datta et al., 2011). Nickel is another beneficial element for plants. It required by the plant in a very little amount for normal plant growth and functioning (Izosimova, 2005). Zinc is a crucial element that influences a number of metabolic processes of plants, it also plays a significant role in producing chlorophyll thus it is vital for normal plant growth (Table 1; Figure 1). Even so beneficial $\mathrm{HM}$ ions like, $\mathrm{Co}, \mathrm{Cu}, \mathrm{Fe}, \mathrm{Mn}, \mathrm{Mo}, \mathrm{Ni}$, and $\mathrm{Zn}$ also regulate plant's ROS scavenging system involving enzymatic and non-enzymatic antioxidants mechanisms (Gill and Tuteja, 2010).

\section{IMPACT OF BENIFICIAL HEAVY METALS ON PLANTS AT HIGH LEVEL}

Plants are frequently sensitive both to the low and high accessibility of some heavy metal ions as essential micronutrient. Beneficial heavy metals at high level could upsets the soil environment that consecutively adversely influences soil fertility, plant growth and development (Reeves and Baker, 2000). The 
TABLE 1 | Effect of beneficial heavy metal on different plants at low level.

\begin{tabular}{|c|c|c|c|c|}
\hline Metals & Plants & $\begin{array}{l}\text { Metal concentration at low } \\
\text { level }\end{array}$ & Impacts on plant & References \\
\hline Co & Cowpea (Vigna unguiculata) & 8 ppm & $\begin{array}{l}\text { Enhanced plant growth and yield. induced nodulation. } \\
\text { maintained the level of mineral composition and chemical } \\
\text { constituent. }\end{array}$ & Gad et al., 2013 \\
\hline Co & Maize (Zea mays L.) & $50 \mathrm{mg} \mathrm{Co} \mathrm{kg}{ }^{-1}$ & $\begin{array}{l}\text { Increased seedling growth, photosynthetic pigments viz., } \\
\text { chlorophyll a, chlorophyll b, and total chlorophyll contents. } \\
\text { Elevatad the level of total sugars, starch, amino acids, } \\
\text { protein content, and mineral content. }\end{array}$ & Jaleel et al., 2008 \\
\hline $\mathrm{Cu}$ & $\begin{array}{l}\text { Wheat (Triticum aestivum cv. } \\
\text { Hasaawi) }\end{array}$ & $2 \mathrm{mM}$ & $\begin{array}{l}\text { Promoted growth and increased biochemical parameters. } \\
\text { increased the biosynthesis of free amino acid, proline, and } \\
\text { activity of antioxidant enzymes. }\end{array}$ & Azooz et al., 2012 \\
\hline $\mathrm{Mn}$ & $\begin{array}{l}\text { Tomato (Lycopersicon } \\
\text { esculentum Mill.) seedling }\end{array}$ & $7.6-8.6 \mathrm{mg} \mathrm{kg}^{-1}$ & $\begin{array}{l}\text { Middle leaves of tomato seedling showed optimal plant } \\
\text { growth. Normal chlorophyll content observed. Elevated the } \\
\text { level of Fe in shoots. Reduced cytosolic CuZn-SOD and } \\
\text { chloroplastic CuZn-SOD activities. }\end{array}$ & Shenker et al., 2004 \\
\hline Mo & Glycyrrhiza uralensis & $0.52 \mathrm{mg} \cdot \mathrm{L}^{-1}$ and $5.2 \mathrm{mg} \cdot \mathrm{L}^{-1}$ & $\begin{array}{l}\text { Promoted the Secondary metabolic process of glycyrrhizic } \\
\text { acid content and its biosynthetic precursor squalene. Also } \\
\text { promoted the expression of the key synthase b-AS gene. }\end{array}$ & Wang et al., 2013 \\
\hline Mo & Bengal gram (Cicer arietinum) & $1.5-4.5 \mathrm{ppm}$ & $\begin{array}{l}\text { Increased root and shoot length. Significantly increased fresh } \\
\text { weight and dry weight of seedling. Increase germination. } \\
\text { Increased ascorbic acid concentration total soluble sugar } \\
\text { and chlorophyll content. }\end{array}$ & Datta et al., 2011 \\
\hline $\mathrm{Zn}$ & Mentha piperita & $1,1.5,2,2.5,3$, and 3.5 ppm & $\begin{array}{l}\text { Recorded increased number of leaves/hactor. Elevated level } \\
\text { of essential oil. enhanced the growth and and yield. }\end{array}$ & Akhtar et al., 2009 \\
\hline $\mathrm{Zn}$ & $\begin{array}{l}\text { Groundnut (Arachis } \\
\text { hypogaea) and wheat } \\
\text { (Triticum aestivum) }\end{array}$ & $2.5,5.0,7.5 \mathrm{~kg} / \mathrm{ha}$ & $\begin{array}{l}\text { Increased kernel yield, improved the kernel weight, oil, and } \\
\text { protien content. incresed biomass production. }\end{array}$ & Rana and Noman, 2016 \\
\hline
\end{tabular}

threshold level at $10 \mathrm{ppm}$ for $\mathrm{Ni}$ and $50 \mathrm{ppm}$ for Co has been proved undamaging for chickpea (Table 2; Figure 1). Ni at more than $50 \mu \mathrm{g} \mathrm{Ni} \mathrm{g}^{-1}$ dry weight negatively affects growth of the plants at multiple levels such as morphological, physiological, and biochemical (Khan et al., 2006). Bakkaus et al. (2005) quoted average Co concentration for plants between 0.1 and $10 \mu \mathrm{g} \mathrm{g}^{-1}$ dry weights and also elaborated the beneficial role of Co for the normal metabolic functioning of plant at low concentration (Table 2; Figure 1). Whereas, several studies has been already proved the toxic effects of $\mathrm{Co}$ at higher concentration that become toxic for the normal plant growth and development and at the same time alters several processes inside plant cell (Parmar and Chanda, 2005; Jayakumar and Vijayarengan, 2006; Jayakumar et al., 2008; Khan et al., 2006; Khan and Khan, 2010). Jayakumar et al. (2008) reported the improved seed germination and increased length of radical and plumule of ragi and paddy at low dose of Co $\left(5 \mu \mathrm{g} \mathrm{L}^{-1}\right)$ while reverse condition was observed at high dosage $\left(25-100 \mu \mathrm{g} \mathrm{Co} \mathrm{L}^{-1}\right)$. Cu in excess hinders plant growth and disables cellular processes such as photosynthesis electron transport (Yruela, 2005). Li et al. (2009) studied toxicity of Co on barley (Hordeum vulgare L.), oilseed rape (Brassica napus L.), tomato (Lycopersicon esculentum L.), and found out that Co has reduced the shoot growth and biomass of the plant (Table 2; Figure 1). Khan and Khan (2010) conducted an experiment on chickpea (Cicer arietinum) to evaluate the effect of nickel and cobalt at lower (0, 10, 50 ppm) and higher (100, 200 , and $400 \mathrm{ppm}$ ) concentrations, obtained result indicated that at high concentration $\mathrm{Ni}$ and $\mathrm{Co}$ induced toxicity in chickpea plant by reducing its growth and biomass, seed germination, chlorophyll content, caused shoot, and root injury, leaf chlorosis, suppression of root nodules and finally it adversely affects the yield of the plant (Table 2; Figure 1). Cu when present in soil in high amount causes cytotoxic injury to plants this resulted in a hindrance of plant growth and caused chlorosis (Lewis et al., 2001). Copper toxicity adversely influence the growth, dry matter, and yield of Vigna radiata (Manivasagaperumal et al., 2011) and growth and oxidative mechanism of tea plant (Camellia sinensis; Dey et al., 2015). De Dorlodot et al. (2005) when plant is subjected to increased $\mathrm{Fe}^{2+}$ uptake and translocation by the plant, Fe toxicity appears (Table 2; Figure 1). Moreover, Arora et al. (2002) stated about the elevated $\mathrm{Fe}^{2+}$ level in plant induces the production of free radicals that causes membrane, DNA and proteins damages (Table 2; Figure 1). Wu, 2016) also studied iron toxicity in rice plant. Mn at higher level become toxic for plant induces several injuries such as the arrest of plant metabolic processes and the distortion in photosynthetic machinery (Ducic and Polle, 2005). Mn was also reported to inhibit root growth in soyabean (Chen et al., 2016). In excess Mn halt plant growth and development by causing interveinal and marginal chlorosis, necrosis, and distorted leaf structure both externally and internally (Kitao et al., 2001), also by reducing photosynthetic rate of the plant, $\mathrm{CO}_{2}$ assimilation and stomatal conductance (Li et al., 2010). The level of 3.0 ppm of Mo on exposed metaltolerant hydrophyte, Trapa natans reported to cause distortion of mesophyll tissue in leaves, at 10 ppm cells get undifferentiated and at 50-600 $\mu \mathrm{M}$ concentration 


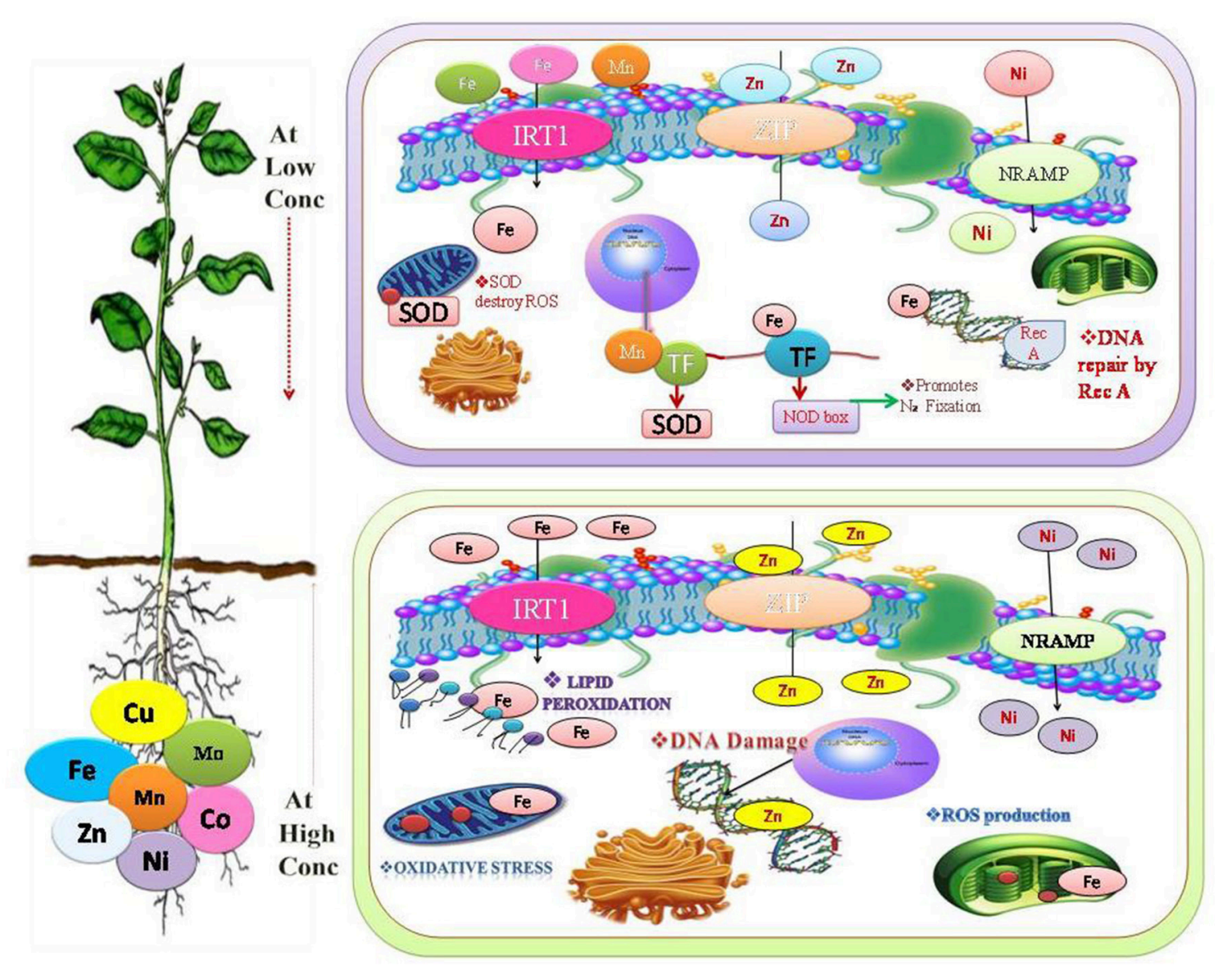

FIGURE 1 | Beneficial heavy metals are play a significant role at low concentration in the synthesis of protein, nucleic acids, photosynthetic pigment, and it also involved in the structural and functional integrity of cell membranes (Oves et al., 2016). Mn promotes antioxidant activity (Shenker et al., 2004), Fe promotes $\mathrm{N}_{2}$-Fixation and DNA repair (Møller et al., 2007). While at high fconcentration it cause substitution of many essential functional groups, for instance, lipid peroxidation (LPO), cellular damage, generation of reactive oxygen species (ROS), disturbance in the various metabolic reaction by altering the enzymatic activity (de Oliveira Jucoski et al., 2013; Anjum et al., 2015).

of Mo caused alteration in the plant morphology, physiology particularly impaired photosynthetic activity (Baldisserotto et al., 2013). Mo in excess is a major factor in reducing plant growth and yield in poorly drained acidic soil, which is a suitable condition for the Mo availability (Rout and Das, 2002). Datta et al. (2011) reported that; in Cicer arietinum Mo concentration more than $7.5 \mathrm{ppm}$ reduced the root and shoot length and at concentration more than $1.5 \mathrm{ppm}$ altered the plant anatomy. Similarly Kumchai et al. (2013) illustrated his study in the context of high level Mo (10 mM) exposed to cabbage (Brassica oleracea), they reported the outcome of study that Mo decreased root and hypocotyls length and cotyledon length and also width (Datta et al., 2011). Izosimova (2005) reported the concentration of $\mathrm{Ni}(200-26,000 \mathrm{mg} / \mathrm{kg})$ in contaminated soil, in comparison to optimum level $\mathrm{Ni}$ concentration $(10-1000 \mathrm{mg} / \mathrm{kg}$ ) in natural soil (Table 2; Figure 1). As stated by Rahman et al. (2005) $\mathrm{Ni}^{2+}$ at elevated level leads to numerous toxicities (chlorosis and necrosis) and physiological modification in plant species. Furthermore, Pandey and Sharma (2002) elaborated that in plant species $\mathrm{Ni}^{2+}$ provoke reduction of water content, this reduction is used to identify $\mathrm{Ni}^{2+}$ stress in plants. Theriault and Nkongolo
(2016) reported about the Nickel and Copper Toxicity in White Birch (Betula papyrifera). According to the Warne et al. (2008) described that the increased concentration of $\mathrm{Zn}$ in soil hinders metabolic functions of plants that causes senescence and delayed growth. At increased concentration $\mathrm{Zn}$ create cytotoxic effect on plant growth and metabolism (Table 2; Figure 1). It leads to major changes in the nucleolus of the root tips cells, cortical cells displayed disruption, and dilution of nuclear membrane at $7.5 \mathrm{mM}$ dose of Zinc (Rout and Das, 2009). Similar results were obtained by Liu et al. (2016) in Solanum nigrum.

\section{AMELIORATING MECHANISM OF BENIFICIAL HEAVY METAL TOXICITY}

HMs such as $\mathrm{Co}, \mathrm{Cu}, \mathrm{Fe}, \mathrm{Mn}, \mathrm{Mo}, \mathrm{Ni}$, and $\mathrm{Zn}$ are considered as beneficial elements that are required in small concentration by the plants, their concentration at high level become toxic for plant at multiple level (Asati et al., 2016). Thus, researchers through different studies suggested the various mechanisms to ameliorate HMs toxicity. Zeid et al. (2013) 
TABLE 2 | Effect of beneficial heavy metal on different plants at high level.

\begin{tabular}{|c|c|c|c|c|}
\hline Metals & Plants & $\begin{array}{l}\text { Metal concentration at high } \\
\text { level }\end{array}$ & Impacts on plant & References \\
\hline Co & Mung beans & $5 \mu \mathrm{M}$ & $\begin{array}{l}\text { Inhibited seedling growth. Caused chlorosis in young leaves. } \\
\text { Reduced the Mn concentration in roots and Fe concentration } \\
\text { in leaves thus inhibited plant growth. }\end{array}$ & Liu et al., 2000 \\
\hline $\mathrm{Co}$ and $\mathrm{Ni}$ & Maize genotypes & 125, 250 mg/L Co 160 mg/L Ni & $\begin{array}{l}\text { Showed negative effects on seed germination index, therefore } \\
\text { reduced maize seed germination. }\end{array}$ & Ebru, 2014 \\
\hline $\mathrm{Co}$ and $\mathrm{Ni}$ & $\begin{array}{l}\text { Chickpea (Cicer } \\
\text { arietinum) }\end{array}$ & 100,200, and 400 ppm & $\begin{array}{l}\text { Reduced Seed germination, plant growth, biomass } \\
\text { production, and leaf chlorophyll content. Suppressed Root } \\
\text { nodulation and decreased number of functional nodules. }\end{array}$ & Khan and Khan, 2010 \\
\hline $\mathrm{Cu}$ & Phaseolus vulgaris & $500 \mu \mathrm{M}$ & $\begin{array}{l}\text { Reduced length and fresh and dry weights of the embryonic } \\
\text { axis of germinating bean seeds. Decreased growth } 50 \% \text {. } \\
\text { Increased level of albumin and globulin content }\end{array}$ & Karmous et al., 2015 \\
\hline $\mathrm{Cu}$ & Withania somnifera & $200 \mu \mathrm{M}$ & $\begin{array}{l}\text { Reduced length of root, shoot, and leaf, and total number of } \\
\text { leaves per plant. Decreased antioxidant activities. Alteration in } \\
\text { protein profile }\end{array}$ & Rout et al., 2013 \\
\hline $\mathrm{Fe}$ & Eugenia uniflora L. & 1.0 and $2.0 \mathrm{mM}$ & $\begin{array}{l}\text { Caused oxidative stress (production of ROS). Reduced root } \\
\text { and shoot growth. Increased lipid peroxidation in leaves. } \\
\text { Increased SOD and GR activity. Limited increase in CAT, POX, } \\
\text { and APX activities while decrease in GPX activity. AA and GSH } \\
\text { contents and the AA/DHA and GSH/GSSG ratios increased. }\end{array}$ & $\begin{array}{l}\text { de Oliveira Jucoski et al., } \\
2013\end{array}$ \\
\hline $\mathrm{Fe}$ & $\begin{array}{l}\text { Sweet potato } \\
\text { (Ipomoea batatas L.). }\end{array}$ & 4.5, and $9.0 \mathrm{mmol} \mathrm{L}^{-1}$ & $\begin{array}{l}\text { Decreased Height, leaf area, and total biomass. Decresed Mn } \\
\text { nutrient concentration. Increased SOD and APX. Reduced } \\
\text { stomatal densities. radical cells displayed mitochondrial } \\
\text { impairment. }\end{array}$ & Adamski et al., 2012 \\
\hline $\mathrm{Fe}$ & $\begin{array}{l}\text { potato (Solanum } \\
\text { tuberosum L.) }\end{array}$ & $0.1-2.0 \mathrm{mM}$ & $\begin{array}{l}\text { Hindered growth, reduced chlorophyll content in older leaves, } \\
\text { and Hill reaction activity. Changed the behavior of enzymatic } \\
\text { activities and Fe and Mn concentration. Decreased sugars, } \\
\text { starch, and protein nitrogen content and elevated the level of } \\
\text { non-protein nitrogen and phenols in tubers thus Reduced } \\
\text { tuber yield and its quality. }\end{array}$ & Chatterjee et al., 2006 \\
\hline $\mathrm{Mn}$ & $\begin{array}{l}\text { Tomato (Lycopersicon } \\
\text { esculentum) }\end{array}$ & $24.0 \mathrm{mg} \mathrm{dm}^{-3}$ & $\begin{array}{l}\text { Reduced fresh weight of leaves, stalks, shoots and fruits, and } \\
\text { biomass production. Declined quality and yield of tomato. } \\
\text { Adversely affects nutrient uptake. }\end{array}$ & Kleiber and Graje, 2015 \\
\hline $\mathrm{Mn}$ & $\begin{array}{l}\text { Chamomile (Matricaria } \\
\text { chamomilla) }\end{array}$ & $1000 \mu \mathrm{M}$ & $\begin{array}{l}\text { Hindered seedling growth. Caused oxidative stress and inhibit } \\
\text { growth of seedling and plant. Decreased POD activity. }\end{array}$ & Kováčik et al., 2014 \\
\hline Mo & $\begin{array}{l}\text { Black gram (Vigna } \\
\text { mungo L.) }\end{array}$ & $2 \mu \mathrm{m}$ & $\begin{array}{l}\text { Declined total dry matter, seed yield, and seed protein, } \\
\text { increased activity of nitrate reductase. Reduced content of } \\
\text { starch, sugars, protein, and nitrogen. Increasing electrical } \\
\text { conductivity of seed leachate thus deteriorated seed quality. }\end{array}$ & Gopal et al., 2015 \\
\hline Mo & $\begin{array}{l}\text { Chickpea (Cicer } \\
\text { arietinum L.) }\end{array}$ & $2 \mathrm{mg} \mathrm{dm}^{-3}$ & $\begin{array}{l}\text { Reduced pod and seed yield, decreased the concentrations of } \\
\text { starch, reducing, non-reducing, and total sugar content. } \\
\text { Declined level of methionine, lysine, legumin, vicilin, total } \\
\text { proteins, and protein and non-protein nitrogen in seeds. } \\
\text { Deteriorated the seed quality by increasing the content of } \\
\text { phenols, cysteine, and albumin. }\end{array}$ & Nautiyal et al., 2005 \\
\hline $\mathrm{Ni}$ & Maize (Zea mays) & $200 \mu \mathrm{m}$ & $\begin{array}{l}\text { Decresed content of chlorophyll a and rate of Hill reaction. } \\
\text { Increased } \mathrm{K}+\text { efflux and carbohydrate leakage from roots and } \\
\text { then cell death of root tips. Increased level of ROS generation. }\end{array}$ & Ghasemi et al., 2012 \\
\hline $\mathrm{Ni}$ & $\begin{array}{l}\text { Potato (Solanum } \\
\text { tuberosum L.) }\end{array}$ & $0.5-0.5 \mathrm{mM}$ & $\begin{array}{l}\text { Decreased levels of sugars, starch, and protein nitrogen and } \\
\text { elevated accumulation of non-protein nitrogen and phenols in } \\
\text { tubers. Increased non-reducing sugars, starch, and phenols } \\
\text { levels in leaves. }\end{array}$ & Shukla, 2010 \\
\hline $\mathrm{Zn}$ & $\begin{array}{l}\text { Wheat seedling } \\
\text { (Triticum aestivum) }\end{array}$ & $3 \mathrm{mM}$ & $\begin{array}{l}\text { Decreased total chlorophyll content and chl a, and chl b. } \\
\text { sygnificantly increased MDA and } \mathrm{H} 2 \mathrm{O} 2 \text { content in leaves. } \\
\text { Increased level of soluble sugar and proline in both leaves and } \\
\text { roots. Inhibited POD and GR activities. }\end{array}$ & Li X. et al., 2013 \\
\hline $\mathrm{Zn}$ & $\begin{array}{l}\text { Tea (Camellia } \\
\text { sinensis L.) }\end{array}$ & $30 \mu \mathrm{M}$ & $\begin{array}{l}\text { Reduced shoot and root fresh and dry weight. Disorganization } \\
\text { of cellular organelles occurred. Reduced net photosynthetic } \\
\text { rate, transpiration rate, stomatal conductance, and } \\
\text { chlorophylls a and b contents. Caused oxidative damage } \\
\text { Elevated the level of ROS generation. }\end{array}$ & $\begin{array}{l}\text { Mukhopadhyay et al., } \\
2013\end{array}$ \\
\hline
\end{tabular}


ameliorated the cobalt toxicity from Medicago sativa by giving the pretreatment of the HMs solutions with precipitation and EDTA (Ethylenediaminetetraacetic acid) that reduced their retarding impact on growth and the metabolic activities. Li et al. (2008) through their experiment on copper stressed Arabidopsis thaliana alleviated the $\mathrm{Cu}$ toxicity by using silicon. Thus, Si (Silicon) decreased the leaf chlorosis, and enhanced root-shoot biomass. It also reduced the stress induced enzyme (phenylalanine ammonia-lyase). Si declined the RNA level of Arabidopsis copper transporter genes; copper transporter 1 (COPT1) and heavy metal ATPase subunit 5 (HMA5). Therefore, $\mathrm{Si}$ proved to improve the plant resistance to $\mathrm{Cu}$ toxicity at multiple levels. Exposure of liming to Juglans regia, Robinia pseudoacacia, Eucalyptus sp., and Populus sp. plantations reported to alleviate $\mathrm{Mn}$ and $\mathrm{Cu}$ toxicity (Chatzistathis et al., 2015). Hajiboland et al. (2013) reported about the role of aluminum $(300 \mu \mathrm{m})$ in reducing $\mathrm{Fe}$ toxicity in tea plant. Whereas, Dufey et al. (2014) reported the application of Si on rice plant to reduce the $\mathrm{Fe}$ generated toxicities. Rogalla and Römheld (2002) studied the toxic effects of Mn from low to high concentration $(0 \cdot 5-1000 \mu \mathrm{M})$ in Cucumis sativus supplied with $\mathrm{Si}$ as sodium silicate at $1.8 \mathrm{mM}$ concentration, which reduced the generated stresses by decreasing $\mathrm{Mn}$ in intercellular washing fluid, mainly in the barium chloride $\left(\mathrm{BaCl}_{2}\right)$ and DTPA (diethylenetriaminepentaacetic acid)-exchangeable fraction of the leaf apoplast, in symplast area. Similar study was also reported by Maksimović et al. (2012) in Cucumber (Cucumis sativus). Si is also known to mitigate manganese mediated toxicities in plants (Liang et al., 2007). Kumchai et al. (2013) studied the role of proline to partially prevail over molybdenum induced stress in cabbage seedling. Plant hormone Gibberellic acid has the potential to alleviate Ni induced stress; it has been proven by the Ali et al. (2015) in mungbeen plant. They further propounded that the application of gibberellic acid on mungbeen improved plant growth and yield. Similarly, another phytohormone jasmonic acid was reported to amend plant growth parameters by reducing $\mathrm{Ni}$ mediated toxicity in Glycine max (Sirhindi et al., 2015). While Siddiqui et al. (2013) reported about the beneficiary role of salisylic acid and nitric oxide (NO) in mitigating Ni stress in wheat. Kaya et al. (2009) gave the exogenous application of $\mathrm{Si}(1.0 \mathrm{mM})$ in maize plant grown in high zinc concentration that enhanced plant growth, chlorophyll content, and relative water content whereas reduced the membrane permeability and proline content. Another study was done by the researchers to alleviate $\mathrm{Zn}$ induced oxidative stress in radish (Raphanus sativus) seedling with the help of plant stress hormone 24-epibrassinolide, that reported to activated the antioxidative enzymatic system (Ramakrishna and Rao, 2012).

\section{CONCLUSION AND FUTURE OUTLOOK}

Soil serves the most important component accruing considerable amount of hazardous chemical pollutants from varying sources per year. Besides behaving as an oversized sink for chemical pollutants soil also serves as a natural buffer by governing the overall transport of chemical substances to the environment. Plants reflect frequent sensitivity to both low and high level concentration of heavy metals, at low level they serves as propitious constituent for plant growth and development but on increasing its concentration beyond threshold limit it will imposes several inimical impacts in plant constituely thereby adversely influencing the soil fertility and development. Slow but perpetual contamination of agricultural soil with heavy metal pollutant may significantly harm the environment and posess the major threats to public health and also build the major issues for subsequent discussion, as it gets accumulated in the soil and shows significant accumulion in agricultural crops. According to the report of FAO (food and agriculture organization of UN) (2009) world population is increasing at a rapid rate and is predicted to reach about 9.6 billion till 2050. Therefore, the future global challenge is to mask the world's hunger through sustainable agriculture and food production. Some HMs such as $\mathrm{Co}, \mathrm{Cu}, \mathrm{Fe}, \mathrm{Mn}, \mathrm{Mo}, \mathrm{Ni}$, and $\mathrm{Zn}$ are considered as beneficial for plant growth and development. Plants require them in a limited quality. Whereas, at high level these metal ions tends to create differential level of toxicity in plant that in turn leads to inhibited plant growth, halt enzymatic and metabolic pathways and also create damages to plant morphology and physiology that eventually reduced overall plant productivity.

Therefore, based on the credible number of research reports it could be well-demarcated that only a required amount of heavy metal could revamp the physiological and morphological characteristics of plants. Thus, it will become essential to exaggerate the further programmes for the improved comprehension of whole mechanism lying behind the synergistic and antagonistic action of heavy metals on plants to perpetuate the ecological harmony of the globe. Considering future perspectives, an efforts should be made to completely alleviate the exagregated level of essential metal ions induced toxicity within the plant tissue. Revealation of transportation mechanism at molecular level should also be made effective in context to plant beneficial HMs ion, as well as reliability of one metal ion on the homeostasis of other metal ion. There is a need of much elaborated research on the mechanism of metal uptake and translocation in relation to their impact on plant growth and development is required to keep pace with healthy agricultural production.

\section{AUTHOR CONTRIBUTIONS}

NA, VY, ShwS, RM, PA, SwS, and DT designed the manuscript, NA, VY, SwS, and DT wrote the manuscript. DT, NKD, PA, ShiS, and DC critically evaluated the manuscript.

\section{FUNDING}

Authors are thankful to the University Grants Commission, New Delhi for financial support. DT: Further extends his thanks to the University Grants Commission for providing Dr. D. S. Kothari Post-Doctoral Fellowship.

\section{SUPPLEMENTARY MATERIAL}

The Supplementary Material for this article can be found online at: http://journal.frontiersin.org/article/10.3389/fenvs. 2016.00069/full\#supplementary-material 


\section{REFERENCES}

Adamski, J. M., Danieloski, R., Deuner, S., Braga, E. J., de Castro, L. A., and Peters, J. A. (2012). Responses to excess iron in sweet potato: impacts on growth, enzyme activities, mineral concentrations, and anatomy. Acta Physiol. Plant. 34, 1827-1836. doi: 10.1007/s11738-012-0981-3

Akhtar, N., Sarker, M. A. M., Akhter, H., and Nada, M. K. (2009). Effect of planting time and micronutrient as zinc chloride on the growth, yield and oil content of Mentha piperita. Bangladesh J. Sci. Ind. Res. 44, 125-130. doi: 10.3329/bjsir.v44i1.2721

Ali, M. A., Asghar, H. N., Khan, M. Y., Saleem, M., Naveed, M., and Niazi, N. K. (2015). Alleviation of nickel-induced stress in mungbean through application of gibberellic acid. Int. J. Agric. Biol. 17, 990-994. doi: 10.17957/IJAB/ 15.0001

Alloway, B. J. (2013). "Heavy metals and metalloids as micronutrients for plants and animals," in Heavy Metals in Soils (Whiteknights: Springer), 195-209.

Anjum, N. A., Duarte, A. C., Pereira, E., and Ahmad, I. (2015). Plant-beneficial elements status assessment in soil-plant system in the vicinity of a chemical industry complex: shedding light on forage grass safety issues. Environ. Sci. Pollut. R. 22, 2239-2246. doi: 10.1007/s11356-014-3478-3

Arora, A., Sairam, R. K., and Srivastava, G. C. (2002). Oxidative stress and antioxidative system in plants. Curr. Sci. 82, 1227-1238.

Asati, A., Pichhode, M., and Nikhil, K. (2016). Effect of heavy metals on plants: an overview. Int. J. Appl. Innov. Eng. Manage. (IJAIEM). 5, 2319-4847.

Azooz, M. M., Abou-Elhamd, M. F., and Al-Fredan, M. A. (2012). Biphasic effect of copper on growth, proline, lipid peroxidation and antioxidant enzyme activities of wheat (Triticum aestivum cv. Hasaawi) at early growing stage. Aust. J. Crop Sci. 6, 688 .

Bakkaus, E., Gouget, B., Gallien, J. P., Khodja, H., Carrot, F., Morel, J. L., et al. (2005). Concentration and distribution of cobalt in higher plants: the use of micro-PIXE spectroscopy. Nucl. Instrum. Methods Phys. Res. B 231, 350-356. doi: 10.1016/j.nimb.2005.01.082

Baldisserotto, C., Ferroni, L., Pantaleoni, L., and Pancaldi, S. (2013). Comparison of photosynthesis recovery dynamics in floating leaves of Trapa natans after inhibition by manganese or molybdenum: effects on photosystem II. Plant Physiol. Biochem. 70, 387-395. doi: 10.1016/j.plaphy.2013.05.044

Barberon, M., and Geldner, N. (2014). Radial transport of nutrients: the plant root as a polarized epithelium. Plant. Physiol. 166, 528-537. doi: $10.1104 /$ pp.114.246124

Barker, A. V., and Pilbeam, D. J. (eds.). (2015). Handbook of Plant Nutrition. Amherst, MA: CRC press.

Baxter, I., Muthukumar, B., Park, H. C., Buchner, P., Lahner, B., Danku, J., et al. (2008). Variation in molybdenum content across broadly distributed populations of Arabidopsis thaliana is controlled by a mitochondrial molybdenum transporter (MOT1). PLoS Genet. 4:e1000004. doi: 10.1371/journal.pgen.1000004

Becana, M., Moran, J. F., and Iturbe-Ormaetxe, I. (1998). Iron-dependent oxygen free radical generation in plants subjected to environmental stress: toxicity and antioxidant protection. Plant Soil. 201, 137-147. doi: 10.1023/A:1004375732137

Becher, M., Talke, I. N., Krall, L., and Krämer, U. (2004). Cross-species microarray transcript profiling reveals high constitutive expression of metal homeostasis genes in shoots of the zinc hyperaccumulator Arabidopsis halleri. Plant J. 37, 251-268. doi: 10.1046/j.1365-313X.2003.01959.x

Bing, H., Wu, Y., Sun, Z., and Yao, S. (2011). Historical trends of heavy metal contamination and their sources in lacustrine sediment from Xijiu Lake, Taihu Lake Catchment, China. J. Environ. Sci. 23, 1671-1678. doi: 10.1016/S10010742(10)60593-1

Blaylock, M. J., and Huang, J. W. (2000). "Phytoextraction of metals," in Phytoremediation of Toxic Metals: Using Plants to Clean Up the Environment, 53-70.

Chabukdhara, M., Munjal, A., Nema, A. K., Gupta, S. K., and Kaushal, R. K. (2016). Heavy metal contamination in vegetables grown around peri-urban and urbanindustrial clusters in Ghaziabad, India. Hum. Ecol. Risk Assess. 22, 736-752. doi: 10.1080/10807039.2015.1105723

Chatterjee, C., Gopal, R., and Dube, B. K. (2006). Impact of iron stress on biomass, yield, metabolism and quality of potato (Solanum tuberosum L.). Sci. Hortic. 108, 1-6. doi: 10.1016/j.scienta.2006.01.004
Chatzistathis, T., Alifragis, D., and Papaioannou, A. (2015). The influence of liming on soil chemical properties and on the alleviation of manganese and copper toxicity in Juglans regia, Robinia pseudoacacia, Eucalyptus sp. and Populus sp. plantations. J. Environ. Manage. 150, 149-156. doi: 10.1016/j.jenvman.2014.11.020

Chen, Z., Yan, W., Sun, L., Tian, J., and Liao, H. (2016). Proteomic analysis reveals growth inhibition of soybean roots by manganese toxicity is associated with alteration of cell wall structure and lignification. J. Proteomics. 143, 151-160. doi: 10.1016/j.jprot.2016.03.037

Chopra, A. K., Pathak, C., and Parasad, G. (2009). Scenario of heavy metal contamination in agricultural soil and its management. J. Appl. Nat. Sci. 1, 99-108.

Colangelo, E. P., and Guerinot, M. L. (2006). Put the metal to the petal: metal uptake and transport throughout plants. Curr. Opin. Plant Biol. 9, 322-330. doi: $10.1016 /$ j.pbi.2006.03.015

Curie, C., Alonso, J. M., Marie, L. E., Ecker, J. R., and Briat, J. F. (2000). Involvement of NRAMP1 from Arabidopsis thaliana in iron transport. Biochem. J. 347, 749-755. doi: 10.1042/bj3470749

DalCorso, G., Manara, A., Piasentin, S., and Furini, A. (2014). Nutrient meta elements in plants. Metallomics 6, 1770-1788. doi: 10.1039/C4MT00173G

Datta, J. K., Kundu, A., Hossein, S. D., Banerjee, A., and Mondal, N. K. (2011). Studies on the Impact of Micronutrient (Molybdenum) on germination, seedling growth and physiology of bengal grain (Cicer arietinum) under laboratory condition. Asian J. Crop Sci. 3, 55-67. doi: 10.3923/ajcs.2011.55.67

De Dorlodot, S., Lutts, S., and Bertin, P. (2005). Effects of ferrous iron toxicity on the growth and mineral composition of an interspecific rice. J. Plant Nutr. 28, 1-20. doi: 10.1081/PLN-200042144

Demirevska-Kepova, K., Simova-Stoilova, L., Stoyanova, Z., Hölzer, R., and Feller, U. (2004). Biochemical changes in barley plants after excessive supply of copper and manganese. Environ. Exp. Bot. 52, 253-266. doi: 10.1016/j.envexpbot.2004.02.004

Deng, W., Li, X., An, Z., and Yang, L. (2016). The occurrence and sources of heavy metal contamination in peri-urban and smelting contaminated sites in Baoji, China. Environ. Monit. Assess. 188, 1-8. doi: 10.1007/s10661-016-5246-y

de Oliveira Jucoski, G., Cambraia, J., Ribeiro, C., de Oliveira, J. A., de Paula, S. O., and Oliva, M. A. (2013). Impact of iron toxicity on oxidative metabolism in young Eugenia uniflora L. plants. Acta Physiol. Plant. 35, 1645-1657. doi: 10.1007/s11738-012-1207-4

Dey, S., Mazumder, P. B., and Paul, S. B. (2015). Copper-induced changes in growth and antioxidative mechanisms of tea plant (Camellia sinensis (L.) O. Kuntze). Afr. J. Biotechnol. 14, 582-592. doi: 10.5897/AJB2014.14279

Ducic, T., and Polle, A. (2005). Transport and detoxification of manganese and copper in plants. Braz. J. Plant Physiol. 17, 103-112. doi: 10.1590/S167704202005000100009

Dufey, I., Gheysens, S., Ingabire, A., Lutts, S., and Bertin, P. (2014). Silicon application in cultivated rices (Oryza sativa $\mathrm{L}$ and Oryza glaberrima Steud) alleviates iron toxicity symptoms through the reduction in iron concentration in the leaf tissue. J. Agron. Crop Sci. 200, 132-142. doi: 10.1111/jac.12046

Ebru, O. G. (2014). Nickel and Cobalt Effects on Maize Germination. Canakkale.

Frassinetti, S., Bronzetti, G. L., Caltavuturo, L., Cini, M., and Della Croce, C. (2006). The role of zinc in life: a review. J. Environ. Pathol. Toxicol. Oncol. 25, 597-610. doi: 10.1615/JEnvironPatholToxicolOncol.v25.i3.40

Gad, N. (2012). Role and importance of cobalt nutrition on groundnut (Arachis hypogaea) production. World Appl. Sci. J. 20, 359-367. doi: 10.5829/idosi.wasj.2012.20.03.2819

Gad, N., and Hassan, N. M. (2013). Role of cobalt and organic fertilizers amendments on tomato production in the newly reclaimed soil. World Appl. Sci. J. 22, 1527-1533. doi: 10.5829/idosi.wasj.2013.22.10.27413

Gad, N., Mohammed, A. M., and Bekbayeva, L. K. (2013). Response of cowpea (Vigna anguiculata) to cobalt nutrition. Middle East J. Sci. Res. 14, 177-184. doi: 10.5829/idosi.mejsr.2013.14.2.2008

Ghasemi, F., Heidari, R., Jameii, R., and Purakbar, L. (2012). Effects of $\mathrm{Ni}^{2+}$ toxicity on Hill reaction and membrane functionality in maize. J. Stress Physiol. Biochem. 8, 55-61.

Gill, M. (2014). Heavy metal stress in plants: a review. Int. J. Adv. Res. 6, 1043-1055. Gill, S. S., and Tuteja, N. (2010). Reactive oxygen species and antioxidant machinery in abiotic stress tolerance in crop plants. Plant Physiol. Biochem. 48, 909-930. doi: 10.1016/j.plaphy.2010.08.016 
Gopal, R., Sharma, Y. K., and Shukla, A. K. (2015). Effect of molybdenum stress on growth, yield and seed quality in black gram. J. Plant Nutr. 39, 463-469. doi: 10.1080/01904167.2015.1016176

Grotz, N., and Guerinot, M. L. (2006). Molecular aspects of Cu, Fe and $\mathrm{Zn}$ homeostasis in plants. Biochim. Biophys. Acta 1763, 595-608. doi: 10.1016/j.bbamcr.2006.05.014

Gupta, N., Ram, H., and Kumar, B. (2016). Mechanism of Zinc absorption in plants: uptake, transport, translocation and accumulation. Rev. Environ. Sci. Biotechnol. 15, 89-109. doi: 10.1007/s11157-016-9390-1

Hajiboland, R., Barceló, J., Poschenrieder, C., and Tolrà, R. (2013). Amelioration of iron toxicity: a mechanism for aluminum-induced growth stimulation in tea plants. J. Inorg. Biochem. 128, 183-187. doi: 10.1016/j.jinorgbio.2013.07.007

Hell, R., and Stephan, U. W. (2003). Iron uptake, trafficking and homeostasis in plants. Planta 216, 541-551. doi: 10.1007/s00425-002-0920-4

Hirayama, T., Kieber, J. J., Hirayama, N., Kogan, M., Guzman, P., Nourizadeh, S., et al. (1999). RESPONSIVE-TO-ANTAGONIST1, a Menkes/Wilson diseaserelated copper transporter, is required for ethylene signaling in Arabidopsis. Cell 97, 383-393. doi: 10.1016/S0092-8674(00)80747-3

Hossain, M. A., Piyatida, P., da Silva, J. A. T., and Fujita, M. (2012). Molecular mechanism of heavy metal toxicity and tolerance in plants: central role of glutathione in detoxification of reactive oxygen species and methylglyoxal and in heavy metal chelation. J. Bot. 2012:37. doi: 10.1155/2012/872875

Hussain, D., Haydon, M. J., Wang, Y., Wong, E., Sherson, S. M., Young, J., et al. (2004). P-type ATPase heavy metal transporters with roles in essential zinc homeostasis in Arabidopsis. Plant Cell 16, 1327-1339. doi: 10.1105/tpc.020487

Hwang, J. U., Song, W. Y., Hong, D., Ko, D., Yamaoka, Y., Jang, S., et al. (2016). Plant ABC transporters enable many unique aspects of a terrestrial plant's lifestyle. Mol. Plant 9, 338-355. doi: 10.1007/s00299-016-2001-3

Izosimova, A. (2005). Modelling the Interaction between Calcium and Nickel in the Soil-Plant System. Bundesforschungsanstalt für Landwirtschaft (Braunschweig: FAL).

Jacobs, J. A., and Testa, S. M. (2005). "Overview of chromium (VI) in the environment: background and history" in Chromium (VI) Handbook, eds J. A. Jacobs, J. Guertin, and C. Avakian (New York: CRC Press), 1-21.

Jaleel, C. A., Changxing, Z., Jayakumar, K., and Iqbal, M. (2008). Low concentration of cobalt increases growth, biochemical constituents, mineral status and yield in Zea mays. J. Sci. Res. 1, 128-137. doi: 10.3329/jsr.v1i1.1226

Jayakumar, K., Jaleel, C. A., and Azooz, M. M. (2008). Impact of cobalt on germination and seedling growth of Eleusine coracana L. and Oryza sativa L. under hydroponic culture. Global J. Mol. Sci. 3, 18-20.

Jayakumar, K., and Vijayarengan, P. (2006). Influence of cobalt on seed germination and seedling growth of Vigna mungo (L.) Hepper. Plant Arch. 6, 681-682.

Kabir, M., Iqbal, M. Z., and Shafiq, M. (2009). Effects of lead on seedling growth of Thespesia populnea L. Adv. Environ. Biol. 184-191.

Kaiser, B. N., Gridley, K. L., Brady, J. N., Phillips, T., and Tyerman, S. D. (2005). The role of molybdenum in agricultural plant production. Ann. Bot. 96, 745-754. doi: 10.1093/aob/mci226

Karmous, I., Bellani, L. M., Chaoui, A., El Ferjani, E., and Muccifora, S. (2015). Effects of copper on reserve mobilization in embryo of Phaseolus vulgaris L. Environ. Sci. Pollut. R. 22, 10159-10165. doi: 10.1007/s11356-0154208-1

Kaya, C., Tuna, A. L., Sonmez, O., Ince, F., and Higgs, D. (2009). Mitigation effects of silicon on maize plants grown at high zinc. J. Plant Nutr. 32, 1788-1798. doi: $10.1080 / 01904160903152624$

Khan, M. R., and Khan, M. M. (2010). Effect of varying concentration of nickel and cobalt on the plant growth and yield of chickpea. Aust. J. Basic Appl. Sci. 4, 1036-1046.

Khan, Z. I., Hussain, A., Ashraf, M., and McDowell, L. R. (2006). Mineral status of soils and forages in southwestern Punjab-Pakistan: micro-minerals. Asian Aust. J. Anim. Sci. 19:1139. doi: 10.5713/ajas.2006.1139

Kim, S. A., and Guerinot, M. L. (2007). Mining iron: iron uptake and transport in plants. FEBS Lett. 581, 2273-2280. doi: 10.1016/j.febslet.2007.04.043

Kitao, M., Lei, T. T., Nakamura, T., and Koike, T. (2001). Manganese toxicity as indicated by visible foliar symptoms of Japanese white birch (Betula platyphylla var. japonica). Environ. Pollut. 111, 89-94. doi: 10.1016/S0269-7491(99) $00332-2$
Kleiber, T., and Graje, K, M. (2015). Tomato reaction on excessive manganese nutrition. Bulg. J. Agric. Sci. 21, 118-125.

Korshunova, Y. O., Eide, D., Clark, W. G., Guerinot, M. L., and Pakrasi, H. B. (1999). The IRT1 protein from Arabidopsis thaliana is a metal transporter with a broad substrate range. Plant Mol. Biol. 40, 37-44. doi: 10.1023/A:1026438615520

Kováčik, J., Babula, P., Hedbavny, J., and Švec, P. (2014). Manganese-induced oxidative stress in two ontogenetic stages of chamomile and amelioration by nitric oxide. Plant Sci. 215, 1-10. doi: 10.1016/j.plantsci.2013.10.015

Krämer, U., Talke, I. N., and Hanikenne, M. (2007). Transition metal transport. FEBS Lett. 581, 2263-2272. doi: 10.1016/j.febslet.2007.04.010

Krzesłowska, M. (2011). The cell wall in plant cell response to trace metals: polysaccharide remodeling and its role in defense strategy. Acta Physiol. Plant. 33, 35-51. doi: 10.1007/s11738-010-0581-Z

Kumchai, J., Huang, J. Z., Lee, C. Y., Chen, F. C., and Chin, S. W. (2013). Proline partially overcomes excess molybdenum toxicity in cabbage seedlings grown in vitro. Genet. Mol. Res. 12, 5589-5601. doi: 10.4238/2013.November.18.8

Lasat, M. M., Pence, N. S., Garvin, D. F., Ebbs, S. D., and Kochian, L. V. (2000). Molecular physiology of zinc transport in the Zn hyperaccumulator Thlaspi caerulescens. J. Exp. Bot. 51, 71-79. doi: 10.1093/jexbot/51.342.71

Lewis, S., Donkin, M. E., and Depledge, M. H. (2001). Hsp70 expression in Enteromorpha intestinalis (Chlorophyta) exposed to environmental stressors. Aquat. Toxicol. 51, 277-291. doi: 10.1016/S0166-445X(00)00119-3

Li, H. F., Gray, C., Mico, C., Zhao, F. J., and McGrath, S. P. (2009). Phytotoxicity and bioavailability of cobalt to plants in a range of soils. Chemosphere 75 , 979-986. doi: 10.1016/j.Chemosphere.2008.12.068

Li, J., Leisner, S. M., and Frantz, J. (2008). Alleviation of copper toxicity in Arabidopsis thaliana by silicon addition to hydroponic solutions. J. Am. Soc. Hortic. Sci. 133, 670-677.

Li, Q., Chen, L. S., Jiang, H. X., Tang, N., Yang, L. T., Lin, Z. H., et al. (2010). Effects of manganese-excess on $\mathrm{CO}_{2}$ assimilation, ribulose-1, 5-bisphosphate carboxylase/oxygenase, carbohydrates and photosynthetic electron transport of leaves, and antioxidant systems of leaves and roots in Citrus grandis seedlings. BMC Plant Biol. 10:42. doi: 10.1186/1471-2229-10-42

Li, S., Zhou, X., Huang, Y., Zhu, L., Zhang, S., Zhao, Y., et al. (2013). Identification and characterization of the zinc-regulated transporters, ironregulated transporter-like protein (ZIP) gene family in maize. BMC Plant Biol. 13:114. doi: 10.1186/1471-2229-13-114

Li, X., Yang, Y., Jia, L., Chen, H., and Wei, X. (2013). Zinc-induced oxidative damage, antioxidant enzyme response and proline metabolism in roots and leaves of wheat plants. Ecotox. Environ. Saf. 89, 150-157. doi: 10.1016/j.ecoenv.2012.11.025

Liang, Y., Sun, W., Zhu, Y. G., and Christie, P. (2007). Mechanisms of siliconmediated alleviation of abiotic stresses in higher plants: a review. Environ Pollut. 147, 422-428. doi: 10.1016/j.envpol.2006.06.008

Liu, J., Reid, R. J., and Smith, F. A. (2000). The mechanism of cobalt toxicity in mung beans. Physiol. Plant. 110, 104-110. doi: 10.1034/j.13993054.2000.110114.x

Liu, X., Chen, J., Wang, G. H., Wang, W. H., Shen, Z. J., Luo, M. R., et al. (2016). Hydrogen sulfide alleviates zinc toxicity by reducing zinc uptake and regulating genes expression of antioxidative enzymes and metallothioneins in roots of the cadmium/zinc hyperaccumulator Solanum nigrum L. Plant Soil 400, 177-192. doi: 10.1007/s11104-015-2719-7

Loftleidir, H. (2005). Essential Trace Elements for Plants, Animals and Humans. Reykjavik.

Lottermoser, B. (2010). Mine Wastes: Characterization, Treatment And Environmental Impacts. Townsville, QLD: Springer Science and Business Media.

Mackie, K. A., Müller, T., and Kandeler, E. (2012). Remediation of copper in vineyards-a mini review. Environ. Pollut. 167, 16-26. doi: 10.1016/j.envpol.2012.03.023

Mahmood, T., and Islam, K. R. (2006). Response of rice seedlings to copper toxicity and acidity. J. Plant Nutr. 29, 943-957. doi: 10.1080/01904160600651704

Maksimović, J. D., Mojović, M., Maksimović, V., Römheld, V., and Nikolic, M. (2012). Silicon ameliorates manganese toxicity in cucumber by decreasing hydroxyl radical accumulation in the leaf apoplast. J. Exp Bot. 63, 2411-2420. doi: $10.1093 /$ jxb/err359 
Emamverdian, A., Ding, Y., Mokhberdoran, F., and Xie, Y. (2015). Heavy metal stress and some mechanisms of plant defense response. Scientific World Journal. 2015:18. doi: 10.1155/2015/756120

Manivasagaperumal, R., Vijayarengan, P., Balamurugan, S., and Thiyagarajan, G. (2011). Effect of copper on growth, dry matter yield and nutrient content of Vigna radiata (L.) Wilczek. J. Phytol. 3, 53-62.

Marschner, H. (1995). "Functions of mineral nutrients: macronutrients," Mineral Nutrition of Higher Plants, 2nd Edn (New York, NY: Academic Press), 299-312.

Marschner, P., and Rengel, Z. (eds.). (2007). Nutrient Cycling in Terrestrial Ecosystems, Vol. 10. Stuttgart: Springer-Verlag.

McCall, K. A., Huang, C. C., and Fierke, C. A. (2000). Function and mechanism of zinc metalloenzymes. J. Nutr. 130, 1437S-1446S.

McGrath, S. P., Micó, C., Curdy, R., and Zhao, F. J. (2010). Predicting molybdenum toxicity to higher plants: Influence of soil properties. Environ. Pollut. 158, 3095-3102. doi: 10.1016/j.envpol.2010.06.027

Mendel, R. R., and Schwarz, G. (2011). Molybdenum cofactor biosynthesis in plants and humans. Coordin. Chem. Rev. 255, 1145-1158. doi: 10.1016/j.ccr.2011.01.054

Millaleo, R., Reyes-Díaz, M., Ivanov, A. G., Mora, M. L., and Alberdi, M. (2010). Manganese as essential and toxic element for plants: transport, accumulation and resistance mechanisms. J. Soil Sci. Plant Nutr. 10, 470-481. doi: 10.4067/S0718-95162010000200008

Mizuno, T., Usui, K., Horie, K., Nosaka, S., Mizuno, N., and Obata, H. (2005). Cloning of three ZIP/Nramp transporter genes from a Ni hyperaccumulator plant Thlaspi japonicum and their Ni 2+-transport abilities. Plant Physiol. Biochem. 43, 793-801. doi: 10.1016/j.plaphy.2005.07.006

Møller, I. M., Jensen, P. E., and Hansson, A. (2007). Oxidative modifications to cellular components in plants. Annu. Rev. Plant Biol. 58, 459-481. doi: 10.1146/annurev.arplant.58.032806.103946

Mukhopadhyay, M., Das, A., Subba, P., Bantawa, P., Sarkar, B., Ghosh, P., et al. (2013). Structural, physiological, and biochemical profiling of tea plantlets under zinc stress. Biol. Plant. 57, 474-480. doi: 10.1007/s10535-0120300-2

Nagajyoti, P. C., Lee, K. D., and Sreekanth, T. V. M. (2010). Heavy metals, occurrence and toxicity for plants: a review. Environ. Chem. Lett. 8, 199-216. doi: 10.1007/s10311-010-0297-8

Nautiyal, N., Singh, S., and Chatterjee, C. (2005). Seed reserves of chickpea in relation to molybdenum supply. J. Sci. Food Agric. 85, 860-864. doi: $10.1002 /$ jsfa. 1929

Oves, M., Khan, S., Qari, H., Felemban, N., and Almeelbi, T. (2016). Heavy Metals: biological importance and detoxification strategies. J. Bioremed. Biodegrad. 7:334. doi: 10.4172/2155-6199.1000334

Pandey, N., and Sharma, C. P. (2002). Effect of heavy metals $\mathrm{Co}^{2+}, \mathrm{Ni}^{2+}$ and $\mathrm{Cd}^{2+}$ on growth and metabolism of cabbage. Plant Sci. 163, 753-758. doi: 10.1016/S0168-9452(02)00210-8

Parmar, N. G., and Chanda, S. (2005). Effects of mercury and chromium on peroxidase and IAA oxidase enzymes in the seedlings of Phaseolus vulgaris. Turk. J. Biol. 29, 15-21.

Pence, N. S., Larsen, P. B., Ebbs, S. D., Letham, D. L., Lasat, M. M., Garvin, D. F., et al. (2000). The molecular physiology of heavy metal transport in the $\mathrm{Zn/Cd}$ hyperaccumulator Thlaspi caerulescens. Proc. Natl. Acad. Sci. U.S.A. 97, 4956-4960. doi: 10.1073/pnas.97.9.4956

Peralta-Videa, J. R., Lopez, M. L., Narayan, M., Saupe, G., and Gardea-Torresdey, J. (2009). The biochemistry of environmental heavy metal uptake by plants: implications for the food chain. Int. J. Biochem. Cell Biol. 41, 1665-1677. doi: 10.1016/j.biocel.2009.03.005

Pichhode, M., and Nikhil, K. (2015). Effect of copper mining dust on the soil and vegetation in india: a critical review. Int. J. Mod. Sci. Eng. Technol. 2, 73-76.

Puig, S., Andrés-Colás, N., García-Molina, A., and PeñArrubia, L. (2007). Copper and iron homeostasis in Arabidopsis: responses to metal deficiencies, interactions and biotechnological applications. Plant Cell Environ. 30, 271-290. doi: 10.1111/j.1365-3040.2007.01642.x

Rahman, H., Sabreen, S., Alam, S., and Kawai, S. (2005). Effects of nickel on growth and composition of metal micronutrients in barley plants grown in nutrient solution. J. Plant Nutr. 28, 393-404. doi: 10.1081/PLN-200049149

Ramakrishna, B., and Rao, S. S. R. (2012). 24-Epibrassinolide alleviated zincinduced oxidative stress in radish (Raphanus sativus L.) seedlings by enhancing antioxidative system. Plant Growth Regul. 68, 249-259. doi: 10.1007/s10725012-9713-3

Rana, D. S., and Noman, H. M. (2016). Effect of zinc levels and zinc bio-fertilizer on the productivity, quality and zinc-use efficiency in groundnut (Arachis hypogaea) and their residual effect on succeeding wheat (Triticum aestivum). Ecol. Perspect. 656.

Reeves, R. D., and Baker, A. J. (2000). "Metal-accumulating plants," Phytoremediation of Toxic Metals: Using Plants to Clean Up the Environment (New York, NY: Wiley), 193-229.

Rengel, Z. (2007). "Cycling of micronutrients in terrestrial ecosystems," in Nutrient Cycling in Terrestrial Ecosystems, eds P. Marschner and Z. Rengel (Berlin; Heidelberg: Springer), 93-121.

Rogalla, H., and Römheld, V. (2002). Role of leaf apoplast in silicon-mediated manganese tolerance of Cucumis sativus L. Plant Cell Environ. 25, 549-555. doi: 10.1046/j.1365-3040.2002.00835.x

Rout, G. R., and Das, P. (2002). Rapid hydroponic screening for molybdenum tolerance in rice through morphological and biochemical analysis. Rost Vyroba 48, 505-512.

Rout, G. R., and Das, P. (2009). "Effect of metal toxicity on plant growth and metabolism: I. Zinc," in Sustainable Agriculture (Nayapalli: Springer), 873-884.

Rout, J. R., Ram, S. S., Das, R., Chakraborty, A., Sudarshan, M., and Sahoo, S. L. (2013). Copper-stress induced alterations in protein profile and antioxidant enzymes activities in the in vitro grown Withania somnifera L. Physiol. Mol. Biol. Plants 19, 353-361. doi: 10.1007/s12298-013-0167-5

Sancenón, V., Puig, S., Mira, H., Thiele, D. J., and Peñarrubia, L. (2003). Identification of a copper transporter family in Arabidopsis thaliana. Plant Mol. Biol. 51, 577-587. doi: 10.1023/A:1022345507112

Shenker, M., Plessner, O. E., and Tel-Or, E. (2004). Manganese nutrition effects on tomato growth, chlorophyll concentration, and superoxide dismutase activity. J. Plant Physiol. 161, 197-202. doi: 10.1078/0176-1617-00931

Shukla, R. (2010). Nickel level and toxicity and metabolism of potato. Int. J. Vegetable Sci. 16, 160-166. doi: 10.1080/19315260903358174

Siddiqui, M. H., Al-Whaibi, M. H., Ali, H. M., Sakran, A. M., Basalah, M. O., and Al Khaishany, M. Y. (2013). Mitigation of nickel stress by the exogenous application of salicylic acid and nitric oxide in wheat. Aust. J. Crop Sci. 7, 1780.

Singh, A., Parihar, P., Singh, R., and Prasad, S. M. (2016). An assessment to show toxic nature of beneficial trace metals: too much of good thing can be bad. Int. J. Curr. Multidisciplinary Stud. 2, 141-144.

Singh, R., Gautam, N., Mishra, A., and Gupta, R. (2011). Heavy metals and living systems: an overview. Indian J. Pharmacol. 43, 246. doi: 10.4103/02537613.81505

Sirhindi, G., Mir, M. A., Sharma, P., Gill, S. S., Kaur, H., and Mushtaq, R. (2015). Modulatory role of jasmonic acid on photosynthetic pigments, antioxidants and stress markers of Glycine max L. under nickel stress. Physiol. Mol. Biol. Plants 21, 559-565. doi: 10.1007/s12298-015-0320-4

Southron, J. L., Basu, U., and Taylor, G. J. (2004). Complementation of Saccharomyces cerevisiae ccc2 mutant by a putative P1B-ATPase from Brassica napus supports a copper-transporting function. FEBS Lett. 566, 218-222. doi: 10.1016/j.febslet.2004.04.035

Tchounwou, P. B., Yedjou, C. G., Patlolla, A. K., and Sutton, D. J. (2012). Heavy metal toxicity and the environment. In Molecular, Clinical and Environmental Toxicology (Basel: Springer), 133-164. doi: 10.1007/978-3-7643-8340-4_6

Theriault, G., and Nkongolo, K. (2016). Nickel and copper toxicity and plant response mechanisms in white birch (Betula papyrifera). Bull Environ. Contam. Toxicol. 97, 171-176. doi: 10.1007/s00128-016-1842-3

Thomine, S., and Lanquar, V. (2011). "Iron transport and signaling in plants," in Transporters and Pumps in Plant Signaling, eds M. Geisler and K. Bemema (Berlin; Heidelberg: Springer), 99-131.

Vert, G., Grotz, N., Dédaldéchamp, F., Gaymard, F., Guerinot, M. L., Briat, J. F., et al. (2002). IRT1, an Arabidopsis transporter essential for iron uptake from the soil and for plant growth. Plant Cell 14, 1223-1233. doi: 10.1105/tpc.001388

Wang, D., Pang, Y. X., Wang, W. Q., Wan, C. Y., Hou, J. L., Yu, F. L., et al. (2013). Effect of molybdenum on secondary metabolic process of glycyrrhizic acid in Glycyrrhiza uralensis Fisch. Biochem. Syst. Ecol. 50, 93-100. doi: 10.1016/j.bse.2013.03.045

Warne, M. S. J., Heemsbergen, D., Stevens, D., McLaughlin, M., Cozens, G., Whatmuff, M., et al. (2008). Modeling the toxicity of copper and zinc salts to wheat in 14 soils. Envirol. Toxicol. Chem. 27, 786-792. doi: 10.1897/07-294.1 
Wu, L. B. (2016). Genetic and Physiological Analyses of the Tolerance Mechanisms to Ferrous Iron Toxicity in Rice (Oryza sativa L.). Doctoral dissertation, Dissertation, Bonn, Rheinische Friedrich-Wilhelms-Universität Bonn.

Wuana, R. A., and Okieimen, F. E. (2011). Heavy metals in contaminated soils: a review of sources, chemistry, risks and best available strategies for remediation. ISRN Ecol. 2011:20. doi: 10.5402/2011/402647

Yruela, I. (2005). Copper in plants. Braz. J. Plant Physiol. 17, 145-156. doi: 10.1590/S1677-04202005000100012

Zeid, I. M., Ghazi, S. M., and Nabawy, D. M. (2013). Alleviation of Co and Cr toxic effects on alfalfa. Int. J. Agron. Plant Prod. 4, 984-993.
Conflict of Interest Statement: The authors declare that the research was conducted in the absence of any commercial or financial relationships that could be construed as a potential conflict of interest.

Copyright (ㄷ 2016 Arif, Yadav, Singh, Singh, Ahmad, Mishra, Sharma, Tripathi, Dubey and Chauhan. This is an open-access article distributed under the terms of the Creative Commons Attribution License (CC BY). The use, distribution or reproduction in other forums is permitted, provided the original author(s) or licensor are credited and that the original publication in this journal is cited, in accordance with accepted academic practice. No use, distribution or reproduction is permitted which does not comply with these terms. 